ДЕРЖАВНА НАУКОВА УСТАНОВА «НАУКОВО-ПРАКТИЧНИЙ ЦЕНТР ПРОФІЛАКТИЧНОЇ ТА КЛІНІЧНОЇ МЕДИЦИНИ» ДЕРЖАВНОГО УПРАВЛІННЯ СПРАВАМИ

\title{
МЕТОДИЧНІ РЕКОМЕНДАЦІї
}

\author{
щодо створення та функціонування \\ репозитарію академічних текстів наукового закладу \\ охорони здоров'я
}

https: / / doi .org/10.31612/guidelines-2022-2

Київ - 2021 
Методичні рекомендації щодо створення та функціонування репозитарію академічних текстів наукового закладу охорони здоров'я / Уклад. Дмитришин В.С.; ДНУ «Науково-практичний центр профілактичної та клінічної медицини» ДУС. - К., 2021. -31 с.

Схвалено Науково-методичною радою ДНУ«Науково-практичний центр профілактичної та клінічної медицини» ДУС

Протокол № 3 від 11 березня 2021 р.

\section{Укладач:}

Дмитришин Володимир Степанович, канд. юр. наук, доцент кафедри інтелектуальної власності (044) 454-79-55

\section{Рецензенти:}

Камишин Володимир Вікторович - в.о. Директора Державної наукової установи «Український інститут науково-технічної експертизи та інформації», доктор педагогічних наук, кандидат технічних наук, старший науковий співробітник, член-кореспондент Національної академії педагогічних наук України, лауреат Державної премії УРСР у галузі науки і техніки та Державної премії України у галузі освіти.

Жарінова Алла Георгіївна - в.о. Директора Державної науково-технічної бібліотеки України, доктор економічних наук.

Методичні рекомендації призначені для використання керівниками та співробітниками наукових і практичних закладів охорони здоров'я, 3 метою допомоги у створенні та функціонування в таких закладах репозитарію академічних текстів. Результатом застосування методичних рекомендацій може бути прийняття управлінських та технічних рішень щодо нормативного, організаційного, матеріально-технічного, кадрового та методичного забезпечення створення і діяльності Репозитарію в науковій установі охорони здоров'я та його інтеграцію в вітчизняну та міжнародну мережу аналогічних сховищ інформації, а також забезпечити контроль за дотриманням в наукові установі правил і норм академічної доброчесності та підвищення якості наукової продукції установи.

(c) Дмитришин В.С.; ДНУ«Науково-практичний центр профілактичної та клінічної медицини» ДУС 


\section{MICT}

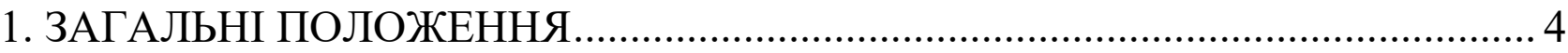

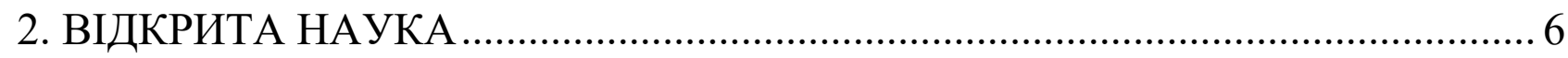

3. РЕПОЗИТАРІЙ, ЯК ІНСТРУМЕНТ ВІДКРИТОЇ НАУКИ............................. 10

4. ПРАВОВІ ЗАСАДИ ФУНКЦІОНУВАННЯ РЕПОЗИТАРІЮ ......................... 14

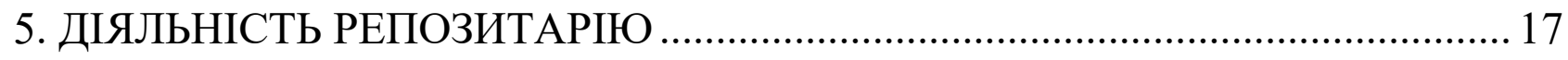

6. ТЕХНІЧНІ АСПЕКТИ ДІЯЛЬНОСТІ РЕПОЗИТАРІЮ..................................26

7. ЗАБЕЗПЕЧЕННЯ АКАДЕМІЧНОЇ ДОБРОЧЕСНОСТІ ...................................... 28

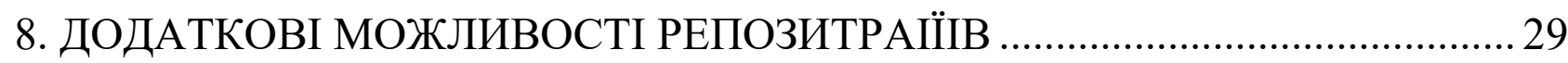

9. ВЗАСМОДІЯ $З$ НАЦІОНАЛЬНИМ РЕПОЗИТАРІЕМ АКАДЕМІЧНИХ

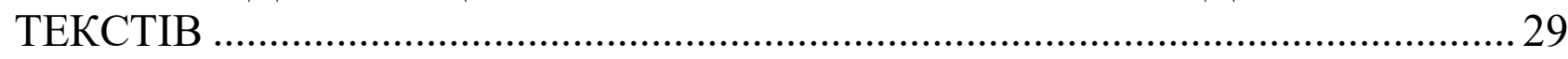

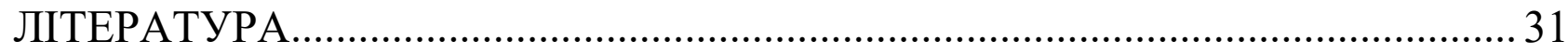




\section{1. ЗАГАЛЬНІ ПОЛОЖЕННЯ}

1. Методичні рекомендації щодо створення та функціонування репозитарію академічних текстів наукового закладу охорони здоров'я (далі Методичні рекомендації) призначені для використання керівниками та співробітниками наукових і практичних закладів охорони здоров'я, з метою допомоги у створенні та функціонування в таких закладах репозитарію академічних текстів.

Результатом застосування методичних рекомендацій може бути прийняття управлінських та технічних рішень щодо нормативного, організаційного, матеріально-технічного, кадрового та методичного забезпечення створення і діяльності Репозитарію в науковій установі охорони здоров'я та його інтеграцію в вітчизняну та міжнародну мережу аналогічних сховищ інформації, а також забезпечити контроль за дотриманням в наукові установі правил і норм академічної доброчесності та підвищення якості наукової продукції установи.

2. У цій сфері діють, зокрема, такі нормативно-правові акти:

- Конституція України;

- Цивільний кодекс України;

- Закони України “Про інформацію”, “Про науково-технічну інформацію”, "Про наукову і науково-технічну діяльність”, "Про вищу освіту”, “Про інноваційну діяльність”, “Про авторське право і суміжні права”, "Про електронні документи та електронний документообіг”, “Про захист інформації в інформаційно-телекомунікаційних системах".

- Постанови Кабінету Міністрів України від 21 жовтня 2015 р. № 835 «Про затвердження Положення про набори даних, які підлягають оприлюдненню у формі відкритих даних», від 19 липня 2017 р. № 541 «Положення про Національний репозитарій академічних текстів»;

- Наказ Міністерства освіти і науки України від 04.07.2018 № 707 «Про затвердження Регламенту роботи Національного репозитарію академічних 
текстів» (Зареєстровано в Міністерстві юстиції України 23 липня 2018 р. за № $858 / 32310)$.

3. Терміни у цих Методичних рекомендаціях використовуються відповідно до зазначених актів. Крім того, у цих Методичних рекомендаціях використовуються такі терміни:

репозитарій академічних текстів наукового закладу охорони здоров'я (далі - Репозитарій) - електронна база даних, в якій накопичуються, зберігаються і систематизуються академічні тексти наукового закладу охорони здоров'я;

відвідувачі Репозитарію (далі - відвідувачі) - фізичні особи, які за допомогою офіційного веб-сайту Репозитарію отримують відкритий доступ до реєстру академічних текстів і можливість користування інформацією без проходження процедури реєстрації (авторизації);

відкритий формат - формат даних, незалежний від платформи та доступний без обмежень, які перешкоджають його повторному використанню;

користувачі Репозитарію - юридичні та фізичні особи, а саме: вищі навчальні заклади, наукові установи, наукові видавництва, бібліотеки, автори та інші заінтересовані особи, що пройшли процедуру реєстрації (авторизації);

розпорядник Репозитарію - посадова особа або підрозділ Установи, яка безпосередньо забезпечує функціонування Репозитарію.

академічний текст - авторський твір наукового, науково-технічного та навчального характеру у формі дисертації, кваліфікаційної випускної роботи, наукового видання, наукової статті, звіту у сфері наукової і науково-технічної діяльності, депонованої наукової роботи, підручника, навчального посібника, інших науково- та навчально-методичних праць;

установа - науковий заклад охорони здоров'я;

творець (творці), автор (автори) об’єкту права інтелектуальної власності фізична особа (особи), творчою працею якого (яких) створено об'єкт права інтелектуальної власності;

персональний електронний кабінет - індивідуальна персоніфікована веб- 
сторінка, за допомогою якої користувач здійснює роботу з відкритими даними, представленими у Національному репозитарії;

договір з працівником - договір з працівником щодо службових об'єктів права інтелектуальної власності та виплати винагороди за їх використання та розпорядження майновими правами на такі об'єкти;

працівник (співробітник) - особа, що працює в Установі за трудовим договором (контрактом) або виконує службове доручення за цивільноправовою угодою;

службовий твір - твір, створений автором у порядку виконання службових обов'язків відповідно до службового завдання чи трудового договору (контракту) між ним і роботодавцем;

службові обов’язки - зафіксовані в трудових договорах (контрактах), посадових інструкціях функціональні обов’язки працівника, що передбачають виконання робіт чи надання медичних послуг, які можуть привести до створення об’єкта інтелектуальної власності, обов'язки працівника з виконання державної тематики, програмно-цільової та конкурсної наукової тематики, відомчої тематики, пошукової та договірної тематики відповідно до перспективних та щорічних планів наукових досліджень, робочих планів 3 виконання теми наукових досліджень Установи;

центральний репозитарій - електронна база даних, в якій накопичуються, зберігаються і систематизуються академічні тексти, у тому числі реєстр академічних текстів, що є частиною Національного репозитарію академічних текстів.

\section{2. ВІДКРИТА НАУКА}

Згідно законодавства України, одним з головних пріоритетів України є прагнення побудувати орієнтоване на інтереси людей, відкрите для всіх i спрямоване на розвиток інформаційне суспільство, в якому кожен міг би створювати і накопичувати інформацію та знання, мати до них вільний доступ, користуватися і обмінюватися ними, щоб надати можливість кожній людині повною мірою реалізувати свій потенціал, сприяючи суспільному і особистому 
розвиткові та підвищуючи якість життя. Основним завданням розвитку інформаційного суспільства в Україні $є$ сприяння кожній людині на засадах широкого використання сучасних інформаційно-комп’ютерних технологій (IKT) можливостей створювати інформацію i знання, користуватися та обмінюватися ними, виробляти товари та надавати послуги, повною мірою реалізовуючи свій потенціал, підвищуючи якість свого життя і сприяючи сталому розвитку країни [1].

Як окремо підкреслюється, залучення IКТ для поліпшення демографічної ситуації, збереження і зміцнення здоров'я населення, підвищення якості та ефективності медико-санітарної допомоги, забезпечення соціальної справедливості та прав громадян на охорону здоров'я є одним з пріоритетних завдань для України.

Впровадження IKT у сферу охорони здоров'я, зокрема, потребує підвищення організаційного i технологічного рівня розвитку IКТ в охороні здоров'я, забезпечення готовності медичних працівників для роботи з ними, забезпечення доступу до світових медичних знань та актуальних на місцевому рівні інформаційних ресурсів 3 метою підвищення ефективного виконання державних дослідницьких i профілактичних програм 3 охорони здоров'я (охорони здоров'я чоловіків і жінок), зокрема щодо репродуктивного здоров'я, інфекційних захворювань (СНІД, малярія, туберкульоз тощо) [1].

Схвалена Урядом України Стратегія розвитку бібліотечної справи на період до 2025 року, зокрема передбачає інтенсивний розвиток та актуалізацію документно-інформаційних ресурсів і забезпечення доступу до них шляхом створення відкритого доступу до наукової інформації через розвиток відкритих електронних архівів [2].

Зазначені тенденції розвитку вітчизняної науки повністю корелюються 3 загальносвітовими тенденціями. Так, у декларації Організації економічного співробітництва та розвитку декларується, що «... міжнародний обмін даними, інформацією та знаннями - значний внесок у розвиток наукових досліджень та інновацій..., відкритий доступ підвищить цінність, отриману від інвестицій суспільства у процес отримання даних» [3]. 
У 2006 році Європейська комісія звернулась до спільноти 3 закликом забезпечити відкритий доступ до результатів досліджень, що фінансуються за державний кошт [4]. В своїх документах Сврокомісія визначає відкриту науку як «перетворення традиційної науки шляхом застосування сучасних інформаційно-комунікаційних технологій з метою зробити процес дослідження відкритим, глобальним, гнучким, ближчим до суспільства. Коли ми говоримо про відкритість науки, ми маємо на увазі шлях, яким здійснюється дослідження, розповсюджуються його результати, здійснюється аналіз» [5].

А затверджений Радою з питань конкурентоспроможності Свропейського Союзу у 2016 році «Амстердамський заклик до дій щодо відкритої науки», передбачає переведення у відкритий доступ до 2020 року всіх наукових публікацій ЄС [6].

Дослідження, проведене у 2004 році. На замовлення Комітету з науки і техніки парламенту Великої Британії рекомендувало усім закладам вищої освіти організовувати інституційні репозитарії, дослідникам - депонувати в них копії своїх статей, а також створити фонд допомоги авторам зі сплати витрат на публікацію статей у журналах відкритого доступу. Була визнана за необхідне фінансова підтримка університетів 3 метою створення архівів відкритого доступу (OAeprint archives); обов'язкове самоархівування статей авторами впродовж місяця після публікації; архівування усіх результатів профінансованих робіт; державне сприяння відкритому доступу як всередині країни, так і за їі межами [7].

Одним 3 визначальних чинників, що вимагають відкритості науки є та обставина, що інформаційне суспільство в сучасних умовах характеризується не тільки блискавичними темпами накопичення та розповсюдження інформації, але i не менш швидким процесом втрати нею актуальності. Враховуючи такі тенденції, важливим наразі є питання не лише створення інформації, але i швидке доведення ii до зацікавлених користувачів. Зазначена мета саме i досягається втіленням принципів відкритої науки. Як зазначають деякі науковці, сучасний світ поділився на два табори: на тих, хто має доступ до усіх наукових здобутків, та на тих, хто такого доступу не має і тому може стати 
вигнанцем у сучасному інформаційному суспільстві. [8]. Саме відкритий доступ до наукової інформації та результатів наукових досліджень може бути тим компромісом, який дозволяє запобігти «інформаційній дискримінації» у сучасному світі.

Загалом, «відкрита наука» - це узагальнюючий термін, що визначає суспільний рух, що ставить собі на меті якого зробити наукові дослідження, наукові дані, нове знання, наукову та науково-технічну інформацію, а також процес їхнього поширення i доведення до споживачів - доступними для суспільства. Споживачами інформації при цьому виступає як науковоакадемічна спільнота, так і для будь-яка особа, зацікавлена у такій інформації. Шляхами розвитку відкритої науки є відкриті публікації результатів досліджень (open research), кампанії на підтримку відкритого доступу (open access), стимулювання вчених до використання «науки 3 відкритим науковим блокнотом» (open notebook science).

Практичне застосування концепції «відкритої науки»:

- дозволяє науковій інформації долати географічні та інституційні межі;

- забезпечує швидке поширення наукової інформації, що не дає науковим даним можливості застарівати, втрачати актуальність;

- стимулює міждисциплінарні дослідження і створення міжнародних дослідницьких груп (колаборацій);

- істотно знижує фінансові бар'єри для отримання даних;

- розширює аудиторію (тепер знання стають доступні для вчених, викладачів, школярів, студентів, підприємців, інноваторів, управлінців, представників засобів масової інформації).

- створює нові майданчики для обговорення результатів наукових досліджень он-лайн 3 одночасним залученням колег до рецензування та координації наукових проектів. Збільшується «видимість» вчених та їх розробок, розширюється коло тих, хто ознайомився з результатами роботи дослідників і послався на отримані ними результати у власних публікаціях або використав пропозиції на практиці [9]. 
BOAI (Будапештська ініціатива відкритого доступу) під «відкритим доступом» розуміє «безкоштовну доступність у загальнодоступному Інтернеті, що дозволяє будь-яким користувачам читати, завантажувати, копіювати, поширювати, друкувати, шукати або посилатись на повні тексти, сканувати їх для індексування, передавати у вигляді даних у програмні продукти або використовувати в будь-яких інших законних цілях без фінансових, юридичних чи технічних бар'єрів, крім тих, які невіддільні від отримання доступу до самого Інтернету». Єдиним прийнятним обмеженням, може бути лише немайнове право автора на недоторканість твору і коректне цитування та визнання. [10].

Ключовими елементами системи відкритості є відкриті архіви, електронні бібліотеки та сховища даних, депозитарії, що діють, як правило, на підставі так званих «вільних ліцензій» [11] і побудовані таким чином, щоб максимально широкому колу зацікавлених осіб надати доступ до знань, наукових розробок і даних, зібраних в результаті експериментів або спеціально проведених спостережень .

\section{2. РЕПОЗИТАРІЙ, ЯК ІНСТРУМЕНТ ВІДКРИТОЇ НАУКИ}

Базовим фінансовим принципом діяльності у сфері відкритого доступу є забезпечення фінансування та покриття збитків на забезпечення доступу до інформації покладається на самого автора або на установу, в якій працює автор. Для осіб, які отримують доступ до інформації, такий доступ і використання $\epsilon$ безкоштовним, безперешкодним, цілодобовим, на відміну від традиційних передплатних моделей, коли витрати компенсуються тими особами, які отримують доступ до інформації.

Вважається, що ця модель надає переваги усім зацікавленим сторонам: організаціям, що фінансують - у вигляді послуг для суспільства та позитивної віддачі від інвестицій у дослідження; авторам - оскільки спонукає до широкого розповсюдження їх робіт; читачам - адже надає доступ до першоджерел; видавцям та рецензентам - оскільки сприяє більш високій оцінці їхньої праці; бібліотекам, яким дозволяє у повній мірі задовольняти різноманітні 
інформаційні запити користувачів; дослідницьким установам та інституціям, збільшуючи їх «видимість», зміцнюючи репутацію та престиж; невеликим видавництвам та науковим громадам, для яких створює стратегічні перспективи для розвитку [9].

Що стосується інформації, яка створюється державними та комунальними науковими установами, то на користь відкритості наукових результатів, отриманих такими установами, свідчить той факт, що більшість досліджень фінансується з державного бюджету, тобто, за кошти суспільства, і відповідно, наукові результати мають належати також суспільству.

У 2016 році в ЄС було прийнято рішення про відкриття до 2020 року для широкого ознайомлення результатів усіх наукових досліджень, які фінансувались за рахунок бюджетних коштів. За новими правилами результати досліджень, що підтримуються державними й державно-приватними фондами будуть в обов'язковому порядку надаватись у відкритий доступ, якщо тільки не існує обгрунтованих причин проти цього (обмеження можуть бути продиктовані вимогами дотримання прав інтелектуальної власності, забезпечення безпеки або збереження конфіденційності інформації) [12].

Прийняте в СС рішення про відритий доступ до результатів досліджень передбачає, що наукові публікації будуть розміщуватись в інституційних сховищах. Причому, якщо згідно з усталеною практикою видання, що не забезпечують відкритий доступ, дозволяють авторам розміщувати власні роботи у доступний для них спосіб з невеликою відстрочкою (наприклад, через 6 або 12 місяців після опублікування), то відповідно до прийнятого в ЄС рішення необхідно, щоб зазначені матеріали ставали доступними у момент опублікування завдяки розміщенню в інституційному депозитарії [9].

Враховуючи зазначене можна стверджувати, що забезпечення відкритості наукових даних медичних установ, які повністю або частково фінансуються 3 державного бюджету є не лише правом таких установ, але і їх обов’язком перед суспільством.

Наукова комунікація має наступні основні складові:

- реєстрація нової ідеї чи дослідження; 
- сертифікація якості дослідження;

- інформування про дослідження та його результати;

- архівування результатів дослідження для майбутнього доступу та використання.

Якщо перші три складові забезпечені, здебільшого, журнальною моделлю розповсюдження інформації, то четверта складова - архівування і збереження завжди були прерогативою бібліотек. Проте, 3 появою Інтернету i впровадженням новітніх інформаційно-комунікаційних технологій ця функція все більше стає властивою для електронних архівів (репозитаріїв). Наразі понад 30\% наукових публікацій вільно доступні в мережі Інтернет, де їх представляють понад 6000 академічних журналів та понад 4500 репозитаріїв.

Репозиторій (англ. repository - сховище, вмістилище, склад) - місце, де зберігаються й підтримуються певні дані. Також репозитарій - це колекція, яка містить певні сутності (дані, інформацію) та може фільтрувати й повертати результат у залежності від вимог користувача [13].

Репозитарії поділяються на:

1. інституційні - належать одній установі: університету, інституту, лабораторії, організації. Таких у світі найбільше - 3091. Серед відомих прикладів - Массачусетський технологічний інститут (DSpace@MIT) [14], eScholarship від Університету Каліфорнії [15], UvA-DARE від Університету Амстердаму [16] та інші;

2. тематичні - охоплюють окремі дисципліни або галузі знань. Наприклад, вже згадуваний ArXiv, CiteSeer, RePEc, Smithsonian NASA ADS, SSRN, PubMed Central (PMC) чи Europe PMC;

3. урядові - належать державним структурам, що забезпечують зберігання та організацію доступу до урядових документів, звітів і т.п.). Наприклад, DAFWA Research Library [17].

4. агрегаційні або міжінституційні - належать консорціуму університетів чи інститутів або окремому проекту. Наприклад, відомі Internet Archive [18], ZENODO [19], архів відкритого доступу від OpenAIRE, CERN. Останній, зокрема, пропонує безкоштовне надання DOI для депозитів та інші 
потрібні для дослідників сервіси.

Кожен репозитарій, в залежності від мети діяльності та його виду, самостійно визначає та встановлює власну політику щодо колекцій, менеджменту, правил та умов доступу. Ознайомитись з типовими підходами до встановлення такої політики можливо, зокрема, завдяки проекту ROARMAP - The Registry of Open Access Repository Mandates and Policies [20], SHERPA або MELIBEA [21].

Види документів, які зберігають у репозитаріях, залежать від місії та політики репозитарію чи наукової установи, що створює репозитарій. Це можуть бути будь-які оцифровані об'єкти наукової, освітньої, адміністративної, культурної діяльності окремого дослідника чи установи. До репозитарію розміщують як нерецензовані недруковані матеріали (препринти, здебільшого авторські рукописи завершених і поданих до журналу статей), так і будь-які постпринти: передусім, рецензовані надруковані в журналах наукові статті, дисертації чи тези/автореферати дисертацій, електронні книги чи розділи книг, патенти, звіти, матеріали конференцій, а також іншу так звану «сіру» літературу - презентації, будь-які зображення та мультимедійні матеріали, аудіо- та відеофайли, комп'ютерні програми, веб-сторінки, набори даних, навчальні об'єкти, видання (газети, бюлетені, стрічки новин тощо), протоколи досліджень, грантові аплікації чи звіти проектів, статистичні дані, навчальні матеріали (окремі лекції, електронні портфоліо, програми курсів, методичні рекомендації тощо), студентські роботи (курсові, дипломні тощо), бібліографічні покажчики і навіть блоги інституцій.

Репозитарії можуть мати значний позитивний ефект для усіх суб'єктів його функціонування у науковій установі, зокрема:

1. Для установи в цілому: підвищення авторитету, рейтингу та відомості в науковому світі; можливість оцінки зацікавленості суспільства та наукової спільноти у діяльності установи; можливість побудови рейтингів наукових працівників та відповідних заходів стимулювання; розвиток наукової комунікації з іншими профільними установами; побудова системи обліку та контролю активності публікацій наукових працівників; розповсюдження 
результатів досліджень, зберігання та ефективне використання наукового потенціалу; запобігання іміджевим втратам для установи завдяки застосування системи перевірки на академічну доброчесність; можливість надання додаткових платних послуг зацікавленим особам.

2. Для наукового підрозділу: розповсюдження матеріалів досліджень; апробація матеріалів досліджень, отримання зворотного зв’язку від наукової спільноти; підвищення індексу цитованості; побудова системи рейтингування науковців підрозділу та відповідного заохочення до підвищення якості наукової продукції; підвищення рівня академічної доброчесності.

3. Безпосередньо для авторів: можливість донести результати своїх досліджень до широкого кола фахівців; підвищення рівня цитованості; можливість налагодження комунікації 3 провідними фахівцями галузі; довгострокове збереження інформації та можливість внесення змін (доповнень, редагувань) до неї; забезпечення фіксації дати створення твору, як засобу захисту авторських прав.

\section{3. ПРАВОВІ ЗАСАДИ ФУНКЦІОНУВАННЯ РЕПОЗИТАРІЮ}

Згідно чинного законодавства, сукупність засобів, ресурсів та пов’язаних 3 ними послуг, які використовуються науковим співтовариством для проведення досліджень на найвищому рівні, що охоплює найважливіші об’єкти наукового устаткування та обладнання або набори приладів, ресурси, що базуються на знаннях (колекції, архіви, депозитарії або банки даних наукової інформації), інфраструктуру, засновану на технології комунікацій (грід, комп'ютери, програмне забезпечення і мережевий зв’язок), та інші структури унікального характеру визначають, як «дослідницька інфраструктура [22]. Такі інфраструктури можуть бути локально розташованими, віртуальними або розподіленими (організована мережа ресурсів), державними або приватними та входити до міжнародних мереж. Таким чином, репозитарії за своїм правовим статусом є елементом дослідницької інфраструктури.

За визначенням статті 5 Закону України «Про наукову та науковотехнічну діяльність» вчений, який є основним суб'єктом наукової і науково- 
технічної діяльності, має право отримувати, передавати та поширювати відкриту науково-технічну інформацію, а наукові установи мають право здійснювати видавничу діяльність наукового, освітнього та просвітницького характеру, виступати в установленому порядку засновниками друкованих засобів масової інформації, наукових видавництв, наукових журналів та наукових видань.

Стаття 46 вищезазначеного Закону до основних принципів державного управління та регулювання у сфері наукової і науково-технічної діяльності відносить принцип свободи поширення відкритої науково-технічної інформації. А стаття 48 встановлює, що базове фінансування основної діяльності державних наукових установ, що фінансуються за рахунок коштів державного бюджету, наукових досліджень університетів, академій, інститутів здійснюється, в тому числі, для забезпечення доступу до науково-технічної інформації та наукової літератури на всіх видах носіїв.

Стаття 20 Закону України «Основи законодавства України про охорону здоров'я» [23] каже, що дослідження, які проводяться академічними i відомчими науковими установами, навчальними закладами та іншими науковими установами і підрозділами або окремими науковцями, фінансуються на конкурсній основі 3 державного бюджету, а також за рахунок будь-яких інших джерел фінансування, що не суперечать законодавству.

Стаття 16 Закону України «Про авторське право i суміжні права» встановлює, що виключне майнове право на службовий твір належить роботодавцю, якщо інше не передбачено трудовим договором (контрактом) та (або) цивільно-правовим договором між автором i роботодавцем. За створення i використання службового твору автору належить авторська винагорода, розмір та порядок виплати якої встановлюються трудовим договором (контрактом) та (або) цивільно-правовим договором між автором i роботодавцем [24].

Враховуючи зазначене можна стверджувати, що наукові установи системи охорони здоров'я володіють майновими правами на результати наукової діяльності співробітників таких установ, що виражені у формі об'єктів 
авторського права та створені за кошти державного бюджету, i доведення таких результатів до суспільного відома $\epsilon$ не тільки правом, але i обов'язком зазначених установ.

Завданнями репозитарію наукового закладу охорони здоров’я є:

- накопичення, збереження, систематизація, обробка у цифровому форматі академічних текстів та інших даних, які створені в Установі;

- інформаційне забезпечення розвитку освіти, науки та інновацій в Установі;

- максимально повне представлення у вітчизняному та світовому науково- освітньому просторі академічних текстів та інших даних і здобутків Установи;

- відтворення, оприлюднення та поширення академічних текстів та інших даних і надання їх зацікавленим користувачам;

- розроблення і впровадження комплексу аналітичних та прикладних інструментів для роботи з академічними текстами та іншими даними Установи;

- оцінювання наукового ландшафту галузі та місце Установи в такому ландшафті;

- надання послуг, пов'язаних із аналітичною та експертною обробкою інформації;

- підтримка академічної доброчесності в Установі;

- сприяння підвищенню ефективності фінансування досліджень.

Власником Репозитарію є Установа. Репозитарій діє на підставі Регламенту, що затверджується Установою. Регламент визначає процедуру наповнення Репозитарію академічними текстами, порядок їх зберігання, систематизації, обробки, надання інформації у відкритий доступ, взаємодії 3 учасниками та користувачами, застосування аналітичних інструментів тощо.

Розпорядник Репозитарію призначається керівництвом Установи та забезпечує використання відомостей репозитарію, надає користувачам доступ до інформації, готує довідники, реєстри, аналітичні матеріали, інші інформаційно-довідкові ресурси, проводить систематизацію та іншу аналітичну роботу відповідно до цього Регламенту згідно із законодавством. 
До Репозитарію включаються всі академічні тексти незалежно від дати їх створення та оприлюднення у визначеному регламентом Репозитарію порядку.

Розпорядник Репозитарію формує реєстр академічних текстів, який $є$ відкритим та містить бібліографічні відомості про академічні тексти, що включені до Репозитарію, а також оприлюднені в електронній або паперовій формі.

Для систематизації академічних текстів Репозитарію використовуються бібліографічні відомості та описи, передбачені законодавством.

Якщо установа здійснює освітню діяльність, то вона розміщує тексти кваліфікаційних випускних робіт здобувачів вищої освіти у Репозитарії, забезпечує доступ до них відповідно до регламенту та вносить їх до центрального репозитарію.

Установа розміщує тексти дисертацій на здобуття наукового ступеня та авторефератів дисертацій у Репозитарії та вносить їх до центрального репозитарію.

Фізичні особи, які є авторами академічних текстів, отримують доступ до Репозитарію в режимі розміщення академічних текстів після проходження відповідної авторизації згідно з регламентом.

Безоплатний і вільний доступ користувачів Репозитарію до інформації, що в ньому міститься, здійснюється через офіційний веб-портал (веб-сторінку) Репозитарію.

\section{5. ДІЯЛЬНІСТЬ РЕПОЗИТАРІЮ}

Репозитарій академічних текстів наукового закладу охорони здоров'я являє собою спеціальним чином організований та структурований загальнодоступний електронний архів, який є ресурсом відкритого доступу, розміщений у мережі Інтернет і доступний для користувачів через мережу Інтернет з будь-якого місця у будь-який час. Ним зможуть користуватись усі, хто погоджується на встановлені правила. При доступі до ресурсів репозитарію не може бути будь-якої дискримінації користувачів, у т.ч. за рівнем освіти, фахом, спеціалізацією та іншими ознаками [9]. 
До репозитарію включаються відкриті дані, тобто інформація, яка не має обмежень для оприлюднення (не містить відомостей, що відповідно до законодавства підлягають охороні від несанкціонованого доступу) i представлена у форматі, який дозволяє ¥ї автоматизовану обробку електронними засобами, вільний і безкоштовний доступ до неї, подальше іiі використання.

В структурі репозитарію, в залежності від його тематичної спрямованості та призначення можуть створюватися окремі тематичні колекції та бази даних, де академічні тексти та інші дані розподіляються за певними критеріями. Такі колекції створюються для вирішення конкретних наукових, освітніх та інноваційних завдань та полегшують пошук необхідної інформації. Репозитарій має складатись 3 модулів або підсистем, структурованих за видами академічних текстів та інших даних, ступенем доступності для ознайомлення та інтегрованістю з аналітичними інструментами.

Окрім того, академічні тексти репозитарію мають поділятись на групи за критерієм режиму доступу на відкриті тексти, та тексти з обмеженим доступом, який встановлюється згідно з чинним законодавством. Якщо за договорами 3 авторами (правовласниками) не передбачена можливість розміщення в репозитарії повної версії твору, то у відкритий сегмент включається його описова частина (бібліографія, анотація, зміст) 3 посиланням на ресурс зберігання матеріалу, а також, за згодою автора (правовласника), окремий фрагмент (частина твору), дозволений для відкритого доступу.

В репозитарії також доцільно створити реферативну базу патентної інформації Установи, яка будується на основі коротких відомостей про патенти, отримані співробітниками Установи та має бути зв'язана 3 базою даних патентів на винаходи та корисні моделі, яку веде Національний орган інтелектуальної власності (ДП «Український інститут інтелектуальної власності»). Також доцільно створити і базу даних об'єктів авторського права, на які видані Свідоцтва про реєстрацію авторського права або договорів щодо розпоряджання правами автора на твір. Така база також має бути зв'язаною 3 базою даних зареєстрованих об'єктів авторського права, яку веде НОІВ 
(Укрпатент).

Доцільним є створення окремого сегменту репозитарію, організованого за принципом соціальної наукової мережі, який призначений для наукової комунікації та самоархівування матеріалів їх авторами - як працівниками Установи, так і іншими фахівцями. Йдеться про платформу для вільного обміну даними, де розміщуються індивідуальні колекції користувачів, що складаються 3 матеріалів, які внесені ними за власною ініціативою у процесі самоархівування, якщо це не протирічить політиці репозитарію, а також буде містити повідомлення, якими вони будуть обмінюватися 3 іншими користувачами. При цьому, розпорядник репозитарію не повинен нести відповідальності за верифікацію даних та їх зміст. Така платформа за своєю суттю є елементом наукової та дослідницької інфраструктури, що представляє собою сукупність інструментів і засобів, реалізованих в мережі Інтернет у формі інтерактивного веб-сайту, призначеного для неформального обміну результатами наукової діяльності (розміщення, обговорення, рецензування, публікації, архівування, зберігання, надання у відкритий доступ, поширення) [9].

Періодичність оновлення колекцій репозитарію визначаються відповідно до політики репозитарію його Розпорядником. Факт надходження академічного тексту до репозитарію та його розміщення в електронній базі фіксується в автоматичному режимі з вказуванням відповідних дат, інформація про що має бути доступна учасникам та користувачам.

Будь-якій особі дозволяється вільно використовувати академічні тексти та інші дані, що містяться у Репозитарії. Суттєвою умовою використання, яка має бути забезпечена технічними засобами репозитарію, $є$ неможливість внесення змін до таких текстів. В межах відкритих ліцензій, тобто умов використання, встановлених автором, копії академічних текстів та інших даних, розміщених у репозитарії, дозволяється відтворювати, представляти чи передавати третій стороні і зберігати в базах даних у будь-якому форматі та на будь-якому носії 3 некомерційною метою без попереднього узгодження. Використання таких текстів та даних дозволяється виключно за умови 
посилання на автора, назву та усі інші обов'язкові елементи бібліографічного опису згідно URL-посилання на сторінку оригінальних метаданих.

Мовами Репозитарію, які використовуються для його інтерфейсу, мають бути українська та англійська.

Хронологічні обмеження для академічних текстів та інших пов'язаних 3 ними даних, що зберігаються у репозитарії, не встановлюються - до нього включаються академічні тексти незалежно від дати їх створення та оприлюднення.

Функціональні можливості Репозитарію мають забезпечувати користувачам наступні можливості:

- ознайомлення 3 реєстром академічних текстів та інших даних, що включені до репозитарію та його тематичних колекцій;

- багатокритерієвий, структурований, багаторівневий пошук інформації за встановленим набором ознак (простий, складний, професійний), - гнучкий, пристосований до потреб різних груп користувачів;

- отримання інформації про наявність повних цифрових/електронних версій або фрагментів академічних текстів та інших даних, а також їх доступність для ознайомлення;

- доступ до повнотекстових версій або фрагментів академічних текстів зі списку/переліку/реєстру, сформованого за результатами індивідуального пошуку, можливість ознайомлення з ними (перегляду) або відсилання до їх джерел;

- збереження інформації в персональному електронному кабінеті користувача або на сумісних зовнішніх приладах для збереження цифрових даних;

- передачу/пересилання інформаціі;

- обробку й трансформацію даних у певний (обраний 3 наданого репозитарієм переліку) формат;

- коректне цитування за чинними стандартами або визнаними правилами і форматами; 
- моніторинг даних про перегляди та завантаження (збереження) інформації користувачами;

- індексування;

- індивідуальне інформування відповідно до оформленої користувачами підписки за набором певних критеріїв на інформацію про оновлення/надходження академічних текстів та інших даних, представлених у репозитарію;

- використання додаткового функціоналу у вигляді спеціально розроблених аналітичних та інших інструментів роботи 3 академічними текстами й іншими даними, включаючи перевірку на плагіат, вимірювання цитованості, отримання даних про публікаційну активність та т.і.;

- отримання інших спеціально замовлених послуг [26].

Розпорядник репозитарію забезпечує:

- правове, організаційне, технічне функціонування репозитарію;

- довготривалий, постійний та надійний віддалений доступ до ресурсів репозитарію;

- накопичення, збереження, систематизацію, відтворення, оприлюднення та поширення в електронному форматі академічних текстів та інших пов’язаних з ними даних;

- моніторинг надходження академічних текстів до репозитарію та надання інформації про використання його ресурсів;

- ведення реєстру академічних текстів та інших даних 3 визначенням доступності повнотекстових версій;

- методологічну та методичну підтримку роботи репозитарію, розроблення та доведення до відома зацікавлених осіб інструктивних матеріалів;

формування та надання у відкритий доступ реєстру академічних текстів;

програмний інтерфейс доступу до репозитарію його учасників;

- інформаційну безпеку та технічну підтримку репозитарію; 
- умови для організації перевірки академічних текстів на наявність збігів текстових (літерних і цифрових символів) та графічних фрагментів;

- аналітичну обробку інформації;

- інформаційне забезпечення розвитку освіти, науки та інновацій в медичній галузі через відкритий доступ до відкритих даних, що містяться у репозитаріі;

- захист та цілісність інформації, що міститься у репозитарію;

- максимально повне представлення академічних текстів, розміщених у репозитарії, у вітчизняному та світовому науково-освітньому просторі, шляхом інформаційної інтеграції з іншими базами даних, зокрема ресурсами відкритих даних України та інших держав, базами центральних органів виконавчої влади;

- підтримку політики відкритої науки і відкритого доступу та необхідні умови для стимулювання видавців і правовласників до передачі електронних версій академічних текстів та інших пов’язаних 3 ними даних i зняття (частково чи повністю) обмежень доступу до них користувачів репозитарію;

- розроблення, впровадження, моніторинг діяльності та використання й подальший розвиток (удосконалення) спеціальних інструментів роботи 3 академічними текстами та іншими даними (завантаження, збереження, структурування, аналіз, обробка, оприлюднення та вилучення);

Розпорядник відповідає за збереження описової, бібліографічної інформації, електронних версій академічних текстів та інших пов’язаних з ними даних, переданих до репозитарію, а також за забезпечення доступу до них користувачам згідно з режимом, визначеним політикою репозитарію та особою, яка розмістила інформацію.

Користувачі репозитарію - це юридичні та фізичні особи, які пройшли процедуру реєстрації (авторизації) з метою отримання доступу до відкритих ресурсів, інструментів та послуг репозитарію

Відвідувачі / гості репозитарію не здійснюють реєстрації на його порталі / 
сайті і мають можливість безкоштовно працювати з ресурсами репозитарію академічними та іншими текстами.

Зареєстрованих користувачів є сенс розподілити на декілька категорій:

- $\quad$ зі стандартним доступом, - ті, що пройшли звичайну процедуру реєстрації (авторизації) в автоматичному режимі;

- 3 розширеним доступом, - які пройшли процедуру реєстрації (авторизаціï) та отримали права використання додаткового функціоналу в силу свого статусу або здійснили оплату додаткових послуг;

зареєстровані користувачі з унікальним доступом - ті, що пройшли процедуру реєстрації (авторизації) та отримали права використання додаткового функціоналу в силу свого статусу або здійснили оплату відповідного пакету обслуговування.

Архівування в репозитарії здійснюється шляхом поетапного заповнення полів, які містять основний набір даних про твір (метаданих) за встановленим переліком, що не $\epsilon$ вичерпним і може коригуватись 3 метою покращення процесу систематизації, розвитку пошукових можливостей системи, розподілу за колекціями, проведення аналітичної роботи тощо.

В Установі репозитарій наповнюється науковими, науково-методичними, навчальними документами шляхом депонування (матеріали розміщують уповноважені депозитори - відповідальні особи, які закріплені у наукових відділах, або безпосередньо працівник розпорядника репозитарію) та самоархівування (матеріали розміщують безпосередньо автори публікацій).

За необхідності академічні тексти можуть вилучатись з репозитарію Розпорядником, а з додаткових ресурсів репозитарію - як користувачами, що розмістили дані шляхом самоархівування, так і Розпорядником (якщо мало місце порушення політики репозитарію щодо академічних текстів та інших даних).

Зміст академічних текстів, розміщених у репозитарії, може бути змінений шляхом доповнення додатковою інформацією (відомостями щодо виявлених друкарських помилок, неточностей, заявами та роз'ясненнями методичного характеру, базами даних досліджень тощо). Будь-яка зміна академічного 
тексту, його описової інформації у реєстрі фіксується відповідною відміткою про дату і причину внесення змін.

Відкликання матеріалів 3 репозитарію здійснюється Розпорядником, учасниками, а також користувачами відповідно до спеціально встановлених власником репозитарію процедур. Підставою для відкликання є порушення авторських та суміжних прав, умов надання у відкритий доступ тощо.

Після відкликання матеріалу 3 репозитарію його копія залишається у закритому для ознайомлення користувачів архіві. В обов'язковому порядку в репозитарії (його відкритій частині) залишаються метадані (описова інформація) про відкликані матеріали з приміткою щодо відкликання.

Правовласники мають право тимчасово або на постійній основі обмежити доступ до електронної версії академічних текстів або їх частини відповідно до чинного законодавства щодо авторських прав. У такому випадку електронні версії академічних текстів, розміщені у репозитарії, стають недоступними для ознайомлення користувачами репозитарію й у подальшому (до зняття обмежень) використовуються виключно Розпорядником в аналітичних цілях та у спосіб відповідно до Закону України «Про авторське право і суміжні права» [24].

На вимогу правовласника, у відкритому доступі може бути представлена лише частина академічного тексту. Яка саме частина може бути відкрита визначає правовласник.

Відвідувачі репозитарію мають можливість:

- отримати відкритий доступ до загальної інформації про репозитарій, інструктивних матеріалів та інших загальних відомостей (умови роботи, структура i наповнення, статистика щодо ресурсів репозитарію, кількості відвідувачів і користувачів, дані щодо звернень до академічних текстів, тощо;

- мати відкритий доступ до реєстру академічних текстів, представлених у репозитарії; 
- $\quad$ здійснювати пошук академічних текстів та інших пов'язаних з ними даних, формувати за індивідуально обраними критеріями список академічних текстів, що зберігаються у репозитарії, уточнювати його, сортувати і зберігати на електронних приладах/носіях;

ознайомлюватись із набором запитань і відповідей, сформованих за результатами спілкування 3 відвідувачами та користувачами репозитарію, контактувати зі службою технічної підтримки репозитарію.

Користувачі проходять процедуру реєстрації у репозитарії, яка підтверджує погодження 3 установленими правилами та Регламентом, i додатково до можливостей, доступних для відвідувачів, мають можливість:

- $\quad$ мати відкритий доступ до електронних версій академічних текстів, можливість ознайомлення 3 ними, збереження їх на електронних приладах/носіях та у персональному електронному кабінеті;

- здійснювати проведення деталізованого пошуку академічних текстів за додатково визначеним набором ознак/критеріїв і збереження його результатів на електронних приладах/носіях та у персональному електронному кабінеті;

- отримати індивідуальне інформування відповідно до оформленої безоплатної підписки щодо оновлення/надходження академічних текстів;

- отримати доступ до додаткових функціональних можливостей репозитарію у вигляді спеціально розроблених аналітичних та інших інструментів роботи з академічними текстами та іншими пов'язаними 3 ними даними [26].

В репозитарії у обов'язковому порядку мають розміщуються твори, які рекомендовані до видання Вченою (Науковою, Науково-методичною) радою Установи та/або видані при повному або частковому фінансуванні Установи у періодичних виданнях Установи. При цьому автори, які розміщують твори у періодичних виданнях Установи, мають бути заздалегідь повідомлені про політику відкритого доступу, яку підтримує Установа, зокрема й щодо 
розміщення творів у електронному архіві.

Репозитарій доцільно реєструвати в світових каталогах (реєстрах) відкритого доступу, наприклад таких, як Довідник репозитаріїв відкритого доступу (Directory of open Access Repositories, DOAR), який індексується у Google Scholar. Також можливо отримання репозитарієм власного Міжнародного стандартного серійного номеру (ISSN), що підтверджує визнання архіву як інформаційного ресурсу та дає йому статус офіційного електронного видання.

\section{6. ТЕХНІЧНІ АСПЕКТИ ДІЯЛЬНОСТІ РЕПОЗИТАРІЮ}

Діяльність репозитарію має бути забезпечена в Установі належним кадровим, технічним, на програмно-коммунікаційним потенціалом. Формати цифрових матеріалів визначаються власником репозитарію, відповідно до його призначення, мети діяльності та політики доступу, визначеними Установою. Обмежень у форматах цифрових матеріалів практично немає: Adobe PDF, Microsoft Powerpoint, Microsoft Excel, JPEG, GIF, MP3, AVI та ін.

Репозитарії мають підтримувати протокол обміну метаданими Ініціативи відкритих архівів OAI-PMH - Open Archives Initiative Protocol for Metadata Harvesting [28], завдяки чому вони повинні бути сумісні 3 іншими ресурсами i користувачі мають мати можливість знайти матеріали таких архівів, навіть не знаючи про їх існування, розташування i зміст. Протокол також має забезпечувати «збирання» (гарвестінг) даних 3 різних репозитаріїв в одну глобальну віртуальну бібліотеку. Для створення й підтримки OAI-сумісних архівів у більшості випадків використовують безкоштовне програмне забезпечення із відкритим кодом. Серед найбільш популярних в світі Dspace, Eprint, BEPress, Fedora, Digital Commons, Greenstone, OPUS, Wildfire та ін. Але $\epsilon$ репозитарії, що використовують комерційне програмне забезпечення (наприклад, Digitool від ExLibris) [9].

Для оприлюднення наборів даних використовуються такі формати [25]: 


\begin{tabular}{c|c}
\hline Тип даних & Формат даних \\
\hline Текстові дані & TXT, RTF, ODT, DOC $(\mathrm{X}), \mathrm{PDF}(3 \mathrm{TeKcTOBим}$
\end{tabular}

Текстові дані

TXT, RTF, ODT, DOC(X), PDF (з текстовим змістом, нескановане зображення), (X)HTML

Структуровані дані RDF, XML, JSON, CSV, XLS(X), ODS, YAML

Графічні дані GI*, TIFF, JPG (JPEG), PNG, GTFS, GTFSRT

Відеодані MPEG, MKV, AVI, FLV, MKS, MK3D

Аудіодані MP3, WAV, MKA

Дані, розроблені $з$

SWF, FLV використанням програми Macromedia Flash

Архів даних ZIP, 7z, Gzip, Bzip2

Геопросторові дані GeoTIFF, SHP, DMF, MID/MIF, DXF, XML, GeoJSON, GPX, LOC, ARINC, AIXM.

Учасники, відвідувачі, користувачі, офіційні партнери та інші особи під час роботи 3 репозитарієм використовують телекомунікаційні мережі загального користування або спеціальні телекомунікаційні мережі.

Для захисту Репозитарію від створення несанкціонованих повних копій його програмне забезпечення має унеможливлювати несанкціоноване зовнішнє копіювання повного змісту Репозитарію або його масштабних частин [26].

Програмне забезпечення репозитраію має забезпечувати можливість: комплексного аналізу запитів користувачів щодо академічних текстів (за тематикою, авторством, належністю до закладів вищої освіти та наукових установ, впровадженням, міжнародною співпрацею тощо);

- комплексного оцінювання використання академічних текстів (у тому числі використання у дисертаціях на здобуття наукових ступенів та кваліфікаційних випускних роботах здобувачів вищої освіти) - читання, скачування, цитування, рекомендації користувачів, зокрема за видами, тематикою, категоріями, у розрізі окремих академічних текстів чи їх 
сукупності, у прив’язці до авторів, наукових підрозділів, тощо, результати якого можуть використовуватись Установою час оцінювання діяльності науковців та наукових підрозділів;

- обудови наукометричної бази даних;

- аналізу цитованості академічних текстів;

- перевірки академічних текстів на наявність збігів текстових (літерних і цифрових символів) та графічних фрагментів.

Забезпечення захисту інформації, що завантажується, обробляється та зберігається в репозитарії, у тому числі персональні дані, здійснюється із застосуванням комплексної системи захисту інформації 3 підтвердженою відповідністю, яка складається із сукупності організаційних та інженернотехнічних заходів, спрямованих на унеможливлення витоку, перехоплення, втрати, знищення, модифікації та блокування інформації [9].

\section{7. ЗАБЕЗПЕЧЕННЯ АКАДЕМІЧНОЇ ДОБРОЧЕСНОСТІ}

Наразі одним 3 важливих аспектів наукової діяльності $є$ вимога забезпечення якості наукових результатів. Запозичення, здійснені без дотримання встановлених законодавством та/або правовласником вимог, визнаються плагіатом і зводять нанівець цінність наукової роботи. Враховуючи зазначене, репозитарій може бути ефективним інструментом забезпечення дотримання в Установі вимог академічної доброчесності. Перевірку усіх робіт, що депонуються співробітниками Установи в репозитраї, доцільно ввести, як обов’язкову вимогу та правило наукової діяльності в Установі.

Таку перевірку доцільно покласти на співробітників підрозділу (чи фахівця), який $є$ Розпорядником репозитарію. 3 технічної точки зору, розпорядник репозитарію має бути забезпечений відповідним програмним забезпеченням та доступом до інформаційних ресурсів, в колекціях яких буде відбуватись пошук текстових співпадінь. Таку перевірку робіт на предмет плагіату забезпечують антиплагіатні комп’ютерні програми, зокрема, українська антиплагіатна програма «Unplag», польська антиплагіатна база 
«StrikePlagiarism», програми відкритого доступу, такі, як: «Etxt Антиплагиат» (AntiPlagiarism.NET), Advego Plagiatus, Shingles Expert тощо.

Запровадження заходів контролю академічної доброчесності здатне значно підвищити якість наукової роботи та стоятиме на варті авторитету i доброго імені Установи.

\section{8. ДОДАТКОВІ МОЖЛИВОСТІ РЕПОЗИТРАЇ̈ІВ}

Враховуючи передбачену законодавством певну фінансову самостійність наукових установ, необхідно зазначити, що ресурси репозитарію дозволяють використовувати його 3 метою надання послуг, які можуть бути як безоплатними, так і оплатними. Так, наприклад, користувачам на підставі платної підписки або на замовлення можуть надаватись послуги з експертизи на наявність текстових запозичень (плагіату), цільовий пошук інформації за критеріями, цікавими замовнику, підготовка аналітичних матеріалів за різною тематикою, аналіз наукового ландшафту, визначення трендів у наукових дослідженнях, оцінка затребуваності інформації та впровадження наукових розробок, електронна доставка документів та т.і..

Окремою функцією може бути відстеження на замовлення авторів або правовласників академічних текстів нових надходжень до репозитарію, інших архівів даних на наявність збігів текстових (літерних і цифрових символів) та графічних фрагментів.

Конкретний перелік послуг і порядок їх надання визначаються власником репозитарію відповідно до політики репозитарію, та формалізуються Регламентом.

\section{9. ВЗАСМОДІЯ З НАЦІОНАЛЬНИМ РЕПОЗИТАРІЕМ АКАДЕМІЧНИХ ТЕКСТІВ}

В Україні, рішенням Уряду [26] з метою сприяння розвитку освітньої, наукової, науково-технічної та інноваційної діяльності шляхом поліпшення доступу до академічних текстів та сприяння академічній доброчесності, створено Національний репозитарій академічних текстів, як загальнодержавну 
розподілену електронну база даних, в якій накопичуються, зберігаються i систематизуються академічні тексти. Власником Національного репозитарію $\epsilon$ держава в особі Міністерства освіти і науки, яке визначає розпорядника Національного репозитарію i затверджує його регламент. Наразі, розпорядником Національного репозитарію визначено Державну наукову установу «Український інститут науково-технічної експертизи та інформації».

Згідно зазначеного рішення інституціональні учасники Національного репозитарію, якими є юридичні особи, зокрема, вищі навчальні заклади, наукові установи, наукові видавництва, організації, бібліотеки, що подають академічні тексти Національному репозитарію, зобов'язані вносити до центрального репозитарію дисертацій та кваліфікаційних випускних робіт здобувачів вищої освіти.

Засновники (співзасновники) наукових та навчальних видань, їх редакції зобов'язані вносити до центрального репозитарію повний бібліографічний опис та анотації публікацій і статей, які розміщуються у відповідних номерах видань, для формування реєстру академічних текстів.

Наукові установи розміщують тексти кваліфікаційних випускних робіт здобувачів вищої освіти у своїх локальних репозитаріях та забезпечують доступ до них відповідно до регламенту. Також наукові установи розміщують тексти дисертацій на здобуття наукового ступеня та авторефератів дисертацій у своїх локальних репозитаріях та вносять до центрального репозитарію [27].

Інституціональні учасники подають до центрального репозитарію бібліографічні відомості, передбачені законодавством, описи академічних текстів, включаючи анотації та списки літератури, що містяться в академічних текстах, з прив'язкою до основного тексту, за переліком, що визначається Розпорядником Національного репозитарію. Ці дані використовуються для систематизації академічних текстів, формування їх реєстру, забезпечення пошукових можливостей Національного репозитарію, проведення аналітичної роботи. Технічні вимоги щодо формату представлення академічних текстів, які включаються до Національного репозитарію, та їх верифікації визначаються його Розпорядником. 
Враховуючи зазначене, Установа має стати інституціональним учасником Національного репозитарію академічних текстів, інтегрувати свій репозитарій 3 Національним репозитарієм та забезпечити виконання вищезазначеної Постанови Уряду.

Така взаємодія дозволить користувачам Національного репозитарію, через його сервіси, мати також доступ до репозитарію Установи, що підвищить присутність Установи в інформаційному просторі та відвідуваність цього pecypcy.

\section{ЛIТЕРАТУРА}

1. Закон України від 9 січня 2007 року № 537-V «Про Основні засади розвитку інформаційного суспільства в Україні на 2007-2015 роки» / Офіційний вісник України від 12.02.2007 - 2007 р., № 8, стор. 9, стаття 273, код акта $38622 / 2007$.

2. Розпорядження Кабінету Міністрів України від 23 березня 2016 р. № 219-р «Про схвалення Стратегії розвитку бібліотечної справи на період до 2025 року “Якісні зміни бібліотек для забезпечення сталого розвитку України” / Урядовий кур'єр від 09.04.2016 - № 68.

3. Declaration on access to research data from public funding (30 Jan.,2004) [Electronic resource] // OECD : Organisation for Economic Cooperation and Development. - URL:

http://acts.oecd.org/Instruments/ShowInstrumentView.aspx?InstrumentID=157 .A headline from the screen.

4. Study on the Economic and Technical Evolution of the Scientific Publication Markets in Europe [Electronic resource]. - URL: http://bit.ly/2sq7bns. A headline from the screen

5. Кучма I. Відкрита наука: практики, успішні кейси, роль бібліотек [Електронний ресурс]/ I. Кучма.

URL:http://ekmair.ukma.edu.ua/bitstream/handle/123456789/11210/Kuch $\underline{\text { ma Vidkry }}$

$\underline{\text { ta nauka.pdf? sequence }=1 \& \text { isAllowed=http://ec.europa.eu/research/openscience }}$ 
/index.cfm. - Заголов. з екрану.

6. Amsterdam Call for Action on Open Science [Electronic resource]. - URL: http://www.openaccess.nl/en/events/amsterdam-call-for-action-on-open-science. - A headline from the screen.

7. Scientific publications : free for all? : tenth report of Session 2003-04/ Great Britain. Parliament. House of Commons. Select Committee on Science and Technology. - London: Stationery Office, 2004.

8. Cribb J. Open science : sharing knowledge in the global century / J. Cribb, S. Tjempaka. - Collingwood, Vic: CSIRO Publishing, 2010. - P. 1.

9. Національний репозитарій академічних текстів: відкритий доступ до наукової інформації : монографія / О. С. Чмир, Т. К. Кваша, Т. О. Ярошенко та ін. - К. : ДНУ «УкрIНТЕІ», 2017. - 200 с.

10. An old tradition and a new technology have converged to make possible an unprecedented public good [Electronic resource] / The Budapest OpenAcces Initiative, $2002 . \quad$ URL:

http://www.budapestopenaccessinitiative.org/boai15-1. - A headline from the screen

11. Creative Commons Web-site [Electronic resource]. - URL: https:// creativecommons.org. - A headline from the screen

12. All scientific papers to be free by 2020 under EU proposals // The guardian. Published 28.05.2016, last modified 22.02.2017 [Electronic resource]. - URL: https://www.theguardian.com/science/2016/may/28/eu-ministers-2020-targetfree-access-scientific-papers/. - A headline from the screen.

13. Паттерн «Репозиторий». Основьі и разьяснения электронньій ресурс]. - URL : https://habrahabr.ru/post/248505/. - Загл. с экрана.

14. Массачусетський технологічний інститут (DSpace@MIT) [Електронний pecypc]. - URL: http://dspace.mit.edu/. - Заголов. з екрану.

15. eScholarship Universite of Colifornia [Electronic resource]. - URL: http://escholarship.org/. - A headline from the screen.

16. UvA-DARE Universite of Amsterdam [Electronic resource]. - URL: http://dare.uva.nl/home. - A headline from the screen.

17. DAFWA Research Library [Electronic resource]. - URL: 
http://researchlibrary.agric.wa.gov.au/. - A headline from the screen.

18. Internet Archive [Electronic resource]. - URL: https://archive.org/. - A headline from the screen.

19. ZENODO [Electronic resource]. - URL: https://zenodo.org/. - A headline from the screen.

20. The Registry of Open Access Repository Mandates and Policies (ROARMAP) [Electronic resource]. - URL: https://roarmap.eprints.org/.

21. Political MELIBEA [Electronic resource]. - URL: http://www.accesoabierto.net/politicas/default.php. - A headline from the screen.

22. Закон України від 26.11.2015 р. № 848-VIII «Про наукову і науковотехнічну діяльність» / Відомості Верховної Ради (ВВР), 2016, № 3, ст.25.

23. Закон України від 19.11.1992 р. № 2801-XII «Основи законодавства України про охорону здоров'я» / Відомості Верховної Ради України від 26.01 .1993 - 1993 р., № 4, стаття 19.

24. Закон України від 23.12.1993 р. N 3792-XII «Про авторське право і суміжні права» / Відомості Верховної Ради України (ВВР), 1994, N 13, ст.64 )

25. Постанови Кабінету Міністрів України від 21 жовтня 2015 р. № 835 «Про затвердження Положення про набори даних, які підлягають оприлюдненню у формі відкритих даних»

26. Постанова Кабінету Міністрів України від 19 липня 2017 р. № 541 Мету, структуру та засади функціонування Репозитарію Положення про Національний репозитарій академічних текстів

27. Наказ Міністерства освітиі і науки України від 04.07.2018 № 707 «Про затвердження Регламенту роботи Національного репозитарію академічних текстів» / Офіційний вісник України від 21.08.2018 - 2018 р., № 64, стор. 137, стаття 2196, код акта 91158/2018

28. Open Archives Initiative Protocol for Metadata Harvesting - OAI-PMH [Electronic resource]. - URL: https://www.openarchives.org/pmh/. - A headline from the screen. 
НАУКОВО-МЕТОДИЧНЕ ВИДАННЯ

\section{МЕТОДИЧНІ РЕКОМЕНДАЦЇ̈ ЩОДО СТВОРЕННЯ ТА ФУНКЦІОНУВАННЯ РЕПОЗИТАРІЮ АКАДЕМІЧНИХ ТЕКСТІВ НАУКОВОГО ЗАКЛАДУ ОХОРОНИ ЗДОРОВ'Я}

Укладач - Дмитришин Володимир Степанович

Макет і компютерна верстка -

Дані типографії: 